\title{
THE METALLIC CONSTITUENTS OF MARINE GASTROPODS
}

\author{
By R. A. McCance, M.D., Ph.D. and L. R. B. Shackleton, Ph.D. \\ Biochemical Laboratory, King's College Hospital, London
}

In 1933 McCance \& Shipp (a) pointed out that one of the common marine molluscs, Littorina littorea, contained between 346 and $507 \mathrm{mg}$. of magnesium per Ioo g. of live weight. While these enormous concentrations of magnesium were not confined to any one organ, the gonads and liver appeared to contain rather more than the foot and mantle. The object of the present paper is to report upon the mineral composition of some of the species allied to L. littorea and also of some of the other gastropods. The chemical methods used have been described in previous publications (McCance \& Shipp I933 $b$; McCance, Widdowson \& Shackleton, I936). The animals were all obtained from the Marine Biological Association at Plymouth, and the analytical results are set out in Table I, the approximate composition of sea water of $33 \%$ salinity being added for comparison (Harvey, I928). When it was necessary to do so, the shells were broken to extract the animals, and in some instances fragments of shell were included in the material taken for analysis. The figures given for calcium, therefore, are in some instances too high, and in one or two cases the amount of calcium carbonate in the material taken has led to appreciable errors in the true water content, e.g. in L. neritoides.

The results which call for comment seem to be:

(I) The animals always contain less sodium than the surrounding water, but the amount of sodium per I00 g. of body water varies on both sides of, and is often not far from the amount of sodium per $100 \mathrm{~g}$. of sea water.

(2) Judged by vertebrate standards, many of the animals contain surprisingly large amounts of potassium. Some of them, notably L. rudis and Lacuna vincta, contain more than $1000 \mathrm{mg}$./100 g., and it would be of considerable interest to know how this potassium was combined.

(3) The calcium in some of these animals may be quite small in amount but is always greater than that in the surrounding sea water, and may be extremely high even in animals in which shell contamination can be absolutely excluded. The most striking instances of this are the two Nudibranchia, forunna and Archidoris, the latter of which contains almost $2.5 \%$ of calcium.

(4) The large amount of magnesium in the winkle (Littorina littorea) is confirmed. In $L$. neritoides and $L$. rudis the magnesium is also very high, but these magnesium contents are not peculiar to the Littorinas, for both Nucella lapillus and Scaphander contain similar amounts of magnesium, and in forunna, and particularly Archidoris, the magnesium concentrations are enormous 
(McCance \& Masters, 1937). It would seem that these marine molluscs may be divided into three groups according to their magnesium contents. The first, as illustrated by Aeolidia, Mytilus edulis and Ostrea edulis (see McCance \& Shipp, I933a) contain much less magnesium than the surrounding water, and it is clear that in this respect their body water must differ radically in composition from the sea. In the second group, of which Pecten maximus, Cardium

\section{TABLE I}

Order and name

MESOGASTROPODA

Littorina littorea

L. littoralis

L. neritoides

L. rudis

Lacuna vincta

ARCHAEOGASTROPODA

Patella vulgata

P. athletica

Calliostoma zizyphinum

STENOGLOSSA

Buccinum undatum

Nucella lapillus

TECTIBRANCHIA

Scaphander lignarius

Aplysia punctata

Nudibranchia

Aeolidia papillosa
Sphaerostoma hombergi

forunna tormentosa

Archidoris britannica
Foot and gut

Gonad and liver

Foot and gut

Gonad and liver

Whole animal

Foot and gut

Gonad and liver

Whole animal

Whole animal

Whole animal

(except radula)

Foot and gut

Gonad and liver

Foot and gut

Gonad and liver

Foot and gut

Gonad and liver

Whole animal

Whole animal

(excluding gastric plates)

Whole animal

Whole animal

Whole animal

Whole animal

Sea water (from Harvey, 1928)

$\begin{array}{ll}79 \cdot 0 & - \\ 89.0 & - \\ 85.0 & 450 \\ 78.0 & 778\end{array}$

$96 \cdot 7 \quad 1033$

Composition per $100 \mathrm{~g}$. of live weight (mg.)

$\begin{array}{rrrrrrr}\begin{array}{c}\text { Water } \\ \text { g. }\end{array} & \mathrm{Na} & \mathrm{K} & \mathrm{Ca} & \mathrm{Mg} & \mathrm{Fe} & \mathrm{Cu} \\ 69 \cdot 5 & 688 & 425 & 82 \mathrm{I} & 456 & 25 \cdot 8 & \mathrm{I} \cdot 77 \\ 64 \cdot 0 & 702 & 425 & 913 & 5 \mathrm{I} 9 & 25 \cdot 6 & 2 \cdot 52 \\ 70 \cdot 0 & 420 & 654 & 1480 & 150 & 9 \cdot 4 & 4 \cdot 73 \\ 60 \cdot 3 & 47 \mathrm{I} & 778 & 4350 & 256 & 15 \cdot 2 & 9 \cdot 13 \\ 6 \mathrm{I} \cdot 0 & 429 & 737 & 4500 & 332 & 26 \cdot 5 & 10 \cdot 2 \\ 67 \cdot 8 & 536 & 1000 & 1285 & 256 & 15 \cdot 6 & 3 \cdot \mathrm{I} \\ 62 \cdot 7 & 695 & 728 & 3700 & 342 & 37 \cdot 5 & 8 \cdot \mathrm{I} \\ 69 \cdot 5 & 724 & \mathrm{IIIO} & 472 & \mathrm{I} 27 & \mathrm{I} 4 \cdot \mathrm{I} & 8 \cdot \mathrm{I}\end{array}$

edule (McCance \& Shipp, I933 a), Buccinum undatum, Aplysia and Sphaerostoma are examples, the concentration of magnesium in the animals is less than that in the surrounding water, but the concentration of magnesium in their body water appears to be close to that in sea water. The third group (Archidoris, Forunna, Littorina littorea, etc.) contains huge concentrations of magnesium. Nothing is known of the state of combination of the metal except in the case of Archidoris (McCance \& Masters, I937), and even in this instance the function of the metal remains a matter of conjecture.

(5) The concentrations of iron vary from 2.5 to II I mg./ $100 \mathrm{~g}$. according 
to the species and organ. The radulae of the Patellidae have formed the basis of a special study (Jones, McCance \& Shackleton, I935).

(6) Judged by mammalian standards, some of the copper concentrations are very high. The gonad and liver of Buccinum may be cited in illustration. At present one can only record the facts without reference to function.

The authors are indebted to Dr E. I. Jones for his collaboration and assistance, particularly in the dissection of the specimens. The work could not have been carried out without the co-operation of the staff of the Marine Biological Association at Plymouth. Certain of the costs were defrayed by the Medical Research Council.

\section{SUMMARY}

The sodium, potassium, calcium, iron and copper have been determined in sixteen marine gastropods, and the results are briefly discussed. A noteworthy finding is the large amount of potassium, calcium and (or) magnesium which may be present in these animals. Lacuna vincta for example may contain over I. I $\%$ of potassium, Archidoris britannica I. $58 \%$ of magnesium per Io0 g. of live weight.

\section{REFERENCES}

Harvey, H. W., 1928. Biological Chemistry and Physics of Sea Water, p. 36. Camb. Univ. Press.

Jones, E. I., McCance, R. A. \& Shackleton, L. R. B., I935. The role of iron and silica in the structure of the radular teeth of certain marine molluscs. Fourn. Exper. Biol., Vol. I2, p. 59.

MCCance, R. A. \& Masters, M. E. M., I937. The chemical composition and the acid base balance of Archidoris britannica. Fourn. Mar. Biol. Assoc., Vol. xxII, p. 273.

MCCanCE, R. A. \& Shipp, H. L., I933a. The magnesium and other inorganic constituents of some marine invertebrates. Fourn. Mar. Biol. Assoc., Vol. xIx, p. 293.

- I933b. The chemistry of flesh foods and their losses on cooking. Spec. Rep. Ser. Med. Res. Counc., London, No. 187.

McCance, R. A., Widdowson, E. M. \& Shackleton, L. R. B., I936. The nutritive value of fruits, vegetables and nuts. Spec. Rep. Ser. Med.Counc.,London, No. 213. 